\title{
Immunválasz és oxidatív stressz hepatitis C-vírus-infekcióban
}

\author{
Pár Alajos dr. - Pár Gabriella dr. \\ Pécsi Tudományegyetem, Általános Orvostudományi Kar, Klinikai Központ, I. Belgyógyászati Klinika, Pécs
}

\begin{abstract}
A szerzők áttekintik a természetes és a szerzett immunválasz jellemzőit hepatitis C-vírus-infekcióban, és röviden tárgyalják a betegség kimenetelét befolyásoló genetikai polimorfizmusokat. Ezenkívül ismertetik a reaktívoxigén-metabolitok és az oxidatív stressz szerepét a hepatitis C-vírus okozta kórfolyamatokban (hepatitis, fibrosis, hepatocellularis carcinoma, steatosis és inzulinrezisztencia). Orv. Hetil., 2015, 156(47), 1898-1903.
\end{abstract}

Kulcsszavak: hepatitis C-vírus, immunválasz, genetikai polimorfizmusok, oxidatív stressz

\section{Immune response and oxidative stress in hepatitis $\mathrm{C}$ virus infection}

\begin{abstract}
This review summarizes our current knowledge on the innate and adaptive immune responses induced by hepatitis $\mathrm{C}$ virus, and on the genetic polymorphisms that may determine the outcome of the disease. In addition, the authors discuss the role of reactive oxygen species and oxidative stress in hepatitis $\mathrm{C}$ virus-related pathogenic processess, such as hepatitis, fibrosis, hepatocellular carcinoma, steatosis and insulin resistance.
\end{abstract}

Keywords: hepatitis C virus, immune response, genetic polymorphisms, oxidative stress

Pár, A., Pár, G. [Immune response and oxidative stress in hepatitis C virus infection]. Orv. Hetil., 2015, 156(47), 1898-1903.

(Beérkezett: 2015. augusztus 18.; elfogadva: 2015. szeptember 23.)

\begin{abstract}
Rövidítések
DAA $=$ direkt ható antivirális szerek; DC-sejtek = dendritikus sejtek; $\mathrm{HCC}=$ hepatocellularis carcinoma; $\mathrm{HCV}=$ hepatitis $\mathrm{C}$ vírus; IFN = interferon; IL = interleukin; NK-sejtek = természetes ölősejtek; PAMP = patogénasszociált molekuláris minta; $\mathrm{PRR}=$ pattern recognition receptorok; TLR = Toll-like receptor
\end{abstract}

Febér János professzor pályája elején ígéretes fiatal patológusként indult, majd klinikusként a májbetegek gyógyításának és a májbetegségek kutatásának szentelte az életét. Az 1970-es években a lueshepatitis első leírásával jegyezte be nevét a nemzetközi irodalomba, és tanulmányokat közölt a májbetegségekben előforduló immunológiai eltérésekról (1. ábra).

Később a szabadgyök-kutatás került érdeklődésének előterébe [1]. Mivel magunk a hepatitis C-vírus (HCV) felfedezését követően szintén az immunitás és az oxidatív stressz kérdéseivel foglalkoztunk, ezért választottuk jelen témánkat a tiszteletére írt dolgozatunkban.

\section{IMMUNVÁLASZ HCV-FERTŐZÉSBEN}

2006-ban az Orvosi Hetilapban áttekintést adtunk a HCV-infekció immunológiájáról és e téren végzett kutatásainkról [2]. Azóta közel egy évtized telt el, ami a HCV-re vonatkozó ismereteink bővülését hozta, bár számos kérdés ma is megoldatlan, például a HCV elleni vakcináció. A direkt ható antivirális szerek (DAA) felfedezésével viszont a víruseliminációhoz (eradikációhoz) vezető terápia korszakába léptünk [3].

A HCV-infekció mindössze az esetek 25\%-ában gyógyul spontán, a fertőzöttek többségében krónikussá válik, és hepatitis, cirrhosis, hepatocellularis carcinoma (HCC) vagy extrahepaticus manifesztációk - mint cryoglobuli- 


\section{EREDEII KÖZLEMÉHYEK}

Semmelweis Orvostudomónyi Egretem,

ill. Belgyógyószoti Klinika (igazgotó! Geró Sándor dr.)

\section{A serum immunglobulinok concentratiojának változása chronicus hepatitisben}

Fehier Jénes $d t$. Johab Lajos do is Szilvósili Istvón de

Orvosi Hetilap, 1973, 114. évfolyam, 9. szám, 491-493.

THE LANCET, NOVEMBER 8, 1975

BARLY SYPHII.ITIC HEPATITIS

\section{J. FенÉR}

3rd Department of Medicine, Semmeitweis Medical University, Budapest, Hungary

Lancet, 1975, 306, 896-899.

1. ábra

| Fehér professzor korai dolgozataiból

naemia, B-sejt-lymphoma, lichen, metabolikus betegség, például diabetes - lehetnek a következmények. A kórfolyamat kimenetelét egyrészt a vírus, másrészt a gazdaszervezet sajátosságai determinálják, mint az életkor, a nem, a társbetegségek, de elsősorban a genetika és az immunválasz $[4,5,6,7]$.

\section{A spontán gyógyuló akut $\mathrm{HCV}$-infekció immunológiája}

HCV-infekcióban a természetes (innate) immunválasz órákon, napokon belül indukálódik, a szerzett (adaptín) válasz 6-8 héttel később.

A természetes immunitás a korai választ képviseli, nem igényel előzetes antigén-szenzitizációt, sem MHC-molekulát, T-sejt-receptort vagy memóriasejteket.

A dendritikus sejtek (DC) és a természetes ölö (NK) -sejtek a fó mediátorok: ezek „pattern recognition receptoraik” (PRR) révén felismerik a „patogénasszociált molekuláris mintákat” (PAMP) és indukálják az antivirális effektor gének expresszióját $[4,5,6,7]$.

$\mathrm{Az}$ NK-sejteken a Toll-like receptor-9 (TLR-9) a DNS-re vonatkozó felismerö receptor, míg a TLR 7/8 az RNS-t ismeri fel. Az innate válaszban az első reakció a TLR-3 receptoron keresztül indukálódó IFN- $\beta$-termelés a hepatocytákban. NK-sejtek direkt citotoxikus potenciával is bírnak, a célsejteket minden előzetes szenzitizálás nélkül támadják $[6,7,8]$.
$\mathrm{Az}$ adaptív válasz antigén-specifikus védekezőmechanizmus az infekció későbbi fázisában. Két ága: a humorális, ami antitestképzésen alapul és a celluláris, amiben a T-sejtek, makrofágok, NK-sejtek és citokinek szerepelnek.

Az antitestek a HCV különböző strukturális és nonstrukturális proteinjeinek epitopjai ellen képződnek. Általában alacsony a titerük, kivéve a $H C V$-core antitestet, ami a celluláris válasz és a transzamináz (GPT) emelkedése idején jelenik meg. Jellemző az $\operatorname{Ig}_{1}$ alosztály dominanciája, valamint, hogy elmarad az $\operatorname{IgG}_{3} \operatorname{IgG}_{4}$-re történő átváltás, ami az antivirális válasz érésére lenne jellemző. Ugyanakkor társulást észleltek az $\mathrm{IgG}_{2}$ és a HCV-clearance között. A HCV-specifikus neutralizáló antitestek protektív hatásúak: az E1 és E2 burok glikoproteinekkel reagálva gátolják a vírus sejthez tapadását, belépését. Ezek korai megjelenését észlelték spontán gyógyuló $\mathrm{HCV}$-infekcióban, amit krónikussá váló esetben csak késóbb lehetett kimutatni $[4,5,6,7]$.

A celluláris válaszban a $H C V$ eliminációjának a kulcsmediátorai a virusspecifikus T-sejtek. A virológiai gyógyulás feltétele, hogy számos epitoppal szemben erős, tartós, poliklonális CD4+és CD8+T-sejt-válasz alakuljon ki [4, $5,6,7]$.

Csimpánzkísérletekben igazolták, hogy a CD8+ és CD4+ T-sejtek depléciója az infekció tartóssá válásához vezet. A CD4+ T-sejtek közül a CDl61+CCR6+ CD26+CD4+ T-sejtek IL-17-et és IL-21-et képeznek, regulációs funkciót képviselnek. A CD8+T-sejtek direkt citotoxicitás és IFN- $\gamma$-képzés révén fejtik ki antivirális hatásukat. Az akut HCV-fertőzést eliminálókban a klinikai manifesztáció (GPT-emelkedés) idején a HCV-specifikus CD4+ T-sejtek proliferációja, IL-2- és IFN- $\gamma$-képzés jellemző - mindez hiányzik a krónikussá válókban $[4,6]$.

\section{Immunválasz krónikus HCV-infekcióban}

\section{Az adaptív válasz elégtelenségének mechanizmusai}

- A CD8+ T-sejtek exhaustiója: a HCV konzervált epitopjai tartós antigénstimulust jelentenek, a kimerülő, funkcionálisan károsodott vírusspecifikus CD8+T-sejtek nem képesek IFN- $\gamma$-t termelni. A T-sejteken a $P D-1$ inhibitoros receptor upregulációja, míg a CD127 receptor alacsony expressziója észlelhető, károsodik a CD127 PD-1 CD8+ T-sejtek proliferációja. A CTLA4 inhibitoros receptor expressziója is fokozódik. Amíg akut HCV-infekcióban az IFN- $\alpha$ helyreállítja a károsodott T-sejt-funkciót, krónikus fertőzésben ez nem észlelhető, azonban a direkt ható antivirális szerek ilyenkor is hatásosak a T-sejtes immunfunkció helyreállításában $[4,8]$.

- Elmenekülés (escape) a T-sejt-felismerés elől, a kvázispeciesek keletkezése révén.

- A HCV direkt sejt-sejt transzfer révén is elmenekülhet az immunválasz elől. 
- Rezisztencia kifejlődése az effektor funkciókkal szemben.

- A CD4+ T-sejtek helper funkciójának elégtelensége.

- Az immunválasz aktív szubverziójára példa az NS5A és E2 által a proteinkináz $\mathrm{R}$ gátlása, a jelátviteli molekulák (RIG-1, TLR-3) leválasztása az NS3/4A által, és az IL-12-képzés módosítása a HCV-core hatására. A TLR-7-mRNS-átírás gátlása következtében csökken a TLR-7 expressziója. HCV hatására a dendritikus sejtekben (DC) az IL-12-képzés csökkenését, az IL-10 fokozott képzését is közölték.

- A HCV E2 protein és az NK-sejt CD81 keresztkötése gátolja az NK-funkciót (IFN-képzést, TNF- $\alpha$ szekréciót) $[4,7,8]$.

- Az IFN- $\lambda$-4-expressziót kontrolláló gén delta-G allélje a HCV csökkent spontán clearance-ével társul, és szoros kapcsolatban van a hepaticus interferonstimulált gén (ISG) fokozott expressziójával és a $\mathrm{P} / \mathrm{R}$ kezelésre való rossz válaszkészséggel [9].

Krónikus C hepatitisben magunk a pegilált interferon+ribavirin $(\mathrm{P} / \mathrm{R})$ kezelésre gyors virológiai válasszal ( $R V R$ ) reagáló (vagyis 4 héten belül vírusnegatívvá váló) betegekben igazoltuk, hogy eseteikben a TLR-4-aktivált monocyták fokozott TNF- $\alpha$ - és IL-6-képzése, az aktivált lymphocyták fokozott IFN- $\gamma$ - és csökkent IL-10- és IL4-képzése jellemző a kezelés előtt. Ez a terápiára nem RVR-betegekben nem volt észlelhető. A P/R fokozta a monocyták TNF- $\alpha$ - és IL-6-képzését, a lymphocyták IFN- $\gamma$-termelését, csökkentette az IL-4- és IL-10-produkciót a jól válaszolókban [10].

$\mathrm{Az}$ NK-sejtek inhibitoros és aktivációs receptorainak expresszióját, citotoxikus aktivitását és citokintermelését vizsgálva azt találtuk, hogy a kontrollhoz képest HCVinfekcióban az NK-sejtek inhibitoros KIR2DL3 és NKG2C receptorexpressziója fokozott, a CDl60, NKG2D és KIR3DLl aktivációs receptoroké csökkent. A TGF- $\beta$-szint fordítottan arányos volt az NKG2Dexpresszióval. Az NK- és a CD8+ T-sejtek IL-4-, IL-10és TNF- $\alpha$-termelése magasabb volt a normális GPT-értékkel járó HCV-infekcióban [11].

\section{A HCV elleni immunitás és a genetikai tényezők kapcsolata}

Az MHC I. osztályú antigének közül a HLA-A*1101, HLA-A*03, HLA-B*57 és HLA-B*27 esetén írtak le védő szerepet a HCV-infekcióval szemben. A HLA-Cl és az NK-sejteken levő inhibitoros receptor KIR2DL3 gyenge kötődése (csökkent inhibitoros szignál) kedvező a víruseliminációra. Hasonlóképp, az NKG2A:CD94 heterodimer és a HLA-E-kötődés hatékony immunválaszszal járt HCV2-fertőzéssel szemben, míg az MHC II. osztályú molekulákat illetően a HLA DRBI*03 és a DQB0*0301 allél társult a HCV spontán clearance-ével $[4,6,7]$.

A citokineket kódoló gének polimorfizmusai közül az IL-12 p40-kódoló gén -1185 SNP CC genotípusa foko- zott IL-12-képződéssel, jó spontán víruseliminációval jár, ugyanezt észlelték az IFN- $\gamma$ promóter régiójában előforduló variáns esetén is. Az $I L-10592$ AA genotípus (csökkent IL-10-képzéssel) víruseliminációra, míg az IL10 -1082 GG allél perzisztálásra hajlamosító szerepét is közölték. A TGF- $\beta-1$ (szupprimálja az NK-aktivitást, IFN- $\gamma$ - és IL-12-képződést) promóter polimorfizmusa -509 C allél (csökkent TGF- $\beta$-expresszióval) fokozott víruseliminációval járt $[4,6,7]$.

Az utolsó évtized felfedezése az IFN- $\lambda$-t kódoló $I L$ $28 B$ gén közelében lévő egy nukleotidot érintő polimorfizmusok (SNP) hatása a HCV eliminációjára. Kiderült, hogy az IL-28B SNP rs12979860 CC genotípusa hajlamosít a HCV spontán clearance-ére, és az IFN-re bekövetkező tartós virológiai remisszióra (SVR) [12]. Hasonló hatású további IL-28B-polimorfizmusokat is leírtak, valamint olyan SNP-t is, amely negatívan befolyásolja az SVR-t $[6,7]$.

Hazai multicentrikus tanulmányunkban az $I L-28 B$ genotípus frekvenciamegoszlásáról kimutattuk, hogy az rs12979860 SNP CC genotípus ritkábban fordult elő HCV-betegekben, mint az egészséges kontrollban $(37,1 \%$ vs. $54,9 \%)$, ami ennek védőhatására utalt. Másrészt az IL-28 CC-pozitív betegek $\mathrm{P} / \mathrm{R}$ terápiára magasabb arányban $(58,6 \%)$ értek el virológiai gyógyulást (SVR), mint a CT genotípusú $(40,8 \%)$ vagy a T-allélt hordozók $(41,8 \%)$. A CC genotípus ezáltal a P/R kezelésre bekövetkező SVR prediktorának bizonyult. Az IL28B genotípusok és a perifériás vér mononukleáris sejtjeinek citokintermelése közötti kapcsolatot illetően igazoltuk, hogy CC genotípusban az LPS indukálta TLR-4-aktiváció a monocyták magas TNF- $\alpha$ produkciójával járt a CT- és TT-variánsokhoz képest. Az aktivált lymphocyták fokozott TNF- $\alpha$-, IL-6-, IL-2-, IFN- $\gamma$-képzése volt észlelhető IL-28B CC genotípusban [13].

Újabban az IL-28 génrégióban a már említett IFN- $\lambda-4$ gén olyan variánsát írták le, amely közvetlenül kontrollálja az IFN- $\lambda$-4-expressziót. Ennek a TT allélje protektív hatású, míg a GG allél magas IFN- $\lambda$-4-szinttel és fokozott hepaticus $I S G$-expresszióval jár, ami kedvezőtlen a vírusclearance szempontjából $[9,14]$.

\section{HCV ÉS OXIDATÍV STRESSZ}

A gyulladásos májbetegségek kutatásában évtizedek óta jelentős helyet foglalt el a szabad gyökök, reaktívoxigénmetabolitok (ROS) okozta károsodások vizsgálata, ami fóként az alkoholos és egyéb toxikus laesiók, illetve a hepatitis B tanulmányozására korlátozódott. A hazai közlemények is ezt tükrözték $[1,15]$.

A HCV felfedezését követően nyilvánvalóvá vált, hogy HCV-fertőzésben is számolni kell az oxidatív stressz szerepével. Egyre több bizonyíték utalt arra, hogy a vírus kiváltotta immunreakcióval kapcsolatos gyulladáson kívül a HCV-proteineknek direkt hatásuk van a ROS-képződésre. HCV-core, E1 és E2 transzgenikus egerekben fo- 
kozott szabadgyök-képződést, oxidatív stresszt, mitokondriumkárosodást írtak le. HCV-core-t expreszszáló tumorsejtekben csökkent mitokondriumpermeabilitást, megnőtt $\mathrm{Ca}^{2+}$-felvételt, fokozott citokróm c-felszabadulást igazoltak. A HCV-core, az NS3 proteáz és az NS5A fokozta a ROS-képződést hepatocyta-sejtkultúrában, romlott a DNS-károsodás helyreállítása, gátolt lett a p53 jelátviteli folyamat, antiapoptotikus hatások érvényesültek. Csökkent az antioxidáns-védelmi funkció, felszaporodtak a DNS oxidációs termékei, például a 8-hidroxi-deoxiguanozin (8-OHdG) nemcsak a fertőzött hepatocytákban, hanem a perifériás vér mononukleáris sejtjeiben is [16, 17].

A HCV-vírusproteinek közül a magban, az endoplazmatikus reticulumban (ER) és a mitokondrium külső membránján lokalizált core hatása bizonyult a legerősebbnek az oxidatív stressz indukálásában, az elektrontranszportkomplex-aktivitás gátlásában, a mitokondrium $\mathrm{Ca}^{2+}$ uniporter aktivitás fokozásában, az ER Ca ${ }^{2+}$-tartalmának csökkenésében, a citoplazmatikus (mitokondriális) $\mathrm{Ca}^{2+-k o n c e n t r a ́ c i o ́ ~ n o ̈ v e l e ́ s e ́ b e n ~[17] ~}$

A HCV által kiváltott oxidatív stresszben a ROS forrásaként a mitokondriumokban az elektrontranszportlánc/oxidatív foszforiláció, a NADPH-oxidázok (NOX1 és NOX-4) és a xantinoxidáz szerepelnek. A HCV-core-t expresszáló sejtekben a mikroszomális CYP2El-aktivitás is jelentős, ami szuperoxid- és $\mathrm{H}_{2} \mathrm{O}_{2}$ képződéssel jár: HCV-betegek hepatocytáiban magas CYP2El-mRNS-szintet mértek, a CYP2E1-aktivitás és a fibrosisscore korrelált [16].

Az utolsó másfél évtizedben derült fény arra, hogy a HCV-infekció nemcsak a hepatitis, a cirrhosis és a HCC keletkezésében játszik szerepet, hanem olyan metabolikus elváltozásokban is, mint a steatosis, az inzulinrezisztencia (IR) és a neurokognitív agyi zavarok. Ezekhez a patológiás elváltozásokhoz különböző molekuláris mechanizmusok vezetnek, közöttük vírusfertőzés hatására kialakuló oxidatív stressz $[16,17]$.

\section{Az oxidatív stressz szerepe HCV okozta kórképekben}

\section{Hepatitis}

A krónikus C hepatitisben a képződő ROS módosítja a nukleinsavakat, proteineket, proteinkinázokat, citokineket és transzkripciós faktorokat. Az oxidatív stressznek a HCV-fertőzésben játszott szerepére utalt a májban és a perifériás mononukleáris sejtekben megváltozott antioxidáns enzimaktivitás, a megnövekedett vagy csökkent szuperoxid dizmutáz (SOD-), glutation-peroxidáz (GPx-) aktivitás, a redukáltglutationszint-csökkenés, a lipidperoxidációs produktum malondialdehid (MDA), illetve a 8-OHdG magas szintje. Igazolhatók voltak a transzaminázértékek és az oxidatív stressz mutatói, például a szérumban az MDA, illetve a 8-OHdG közötti korreláció. A HCV-infekció által aktivált immunválasz különösen a makrofágokban - $\operatorname{ROS}\left(\mathrm{H}_{2} \mathrm{O}_{2}\right)$, valamint citokinek (TNF- $\alpha)$ képződését váltja ki, ezek károsítják a környező hepatocytákat [16]. HCV-betegekben magunk kimutattuk egyrészt az MDA magas szérumszintjét, másrészt az antioxidáns enzimek (SOD, GXP) adaptív aktivitásának növekedését és a kataláz mérsékelt csökkenését [18].

\section{Fibrosis}

A HCV ROS-dependens módon TGF- $\beta$-1-et indukál a hepatocytákban és Kupffer-sejtekben: mind a szérumMDA, mind TGF- $\beta$-1-szint korrelált a fibrosisscorral. A TGF- $\beta$-1-expressziót fokozta az NS3/4A, NS4B és NS5A. A HCV-fertőzött májsejtekből származó apoptotikus testeket a stellatumsejtek (HSC) felveszik, aktiválódnak, de a $H C V$-core és $E 2$ protein is interakcióba lép a HSC-kel, mindezt fokozott TGF- $\beta$-1-képzés és fibrogenesis kíséri [16, 19].

\section{Hepatocellularis carcinoma (HCC)}

A $H C V$-core transzgén egerek direkt bizonyítékkal szolgáltak a HCV és HCC kapcsolatára. A HCC keletkezésének fóbb mechanizmusai:

1. Az infekció által kiváltott ROS-eredetű DNS-károsodások mutációkhoz vezetnek.

2. A HCV-NS5A gátolja a Kv2.1. káliumcsatornát, ezáltal az apoptózist, elősegíti a sejtproliferációt.

3. A HCV-core gátolja a p53-acetilációt (antiapoptotikus hatás) és a DNS-repair szisztémát.

4. A HCV-infekció fokozza a ciklooxigenáz-2(COX-2-) aktivitást, ezáltal a prosztaglandin E2(PGE2-) képzést, a PGE2 aktiválja az antiapoptotikus $\mathrm{PI} 3 \mathrm{~K} / \mathrm{AKT}$ jelátviteli rendszert.

5. A HCV fokozza a vascularis endothelialis növekedési faktor (VEGF-) termelést és az angiogenezist [16, $19,20]$.

\section{Inzulinrezisztencia (IR) és steatosis}

A HCV okozta steatosisban egyrészt az oxidatív stressznek, másrészt a $H C V$-core hatásának tulajdonítottak szerepet. $\mathrm{HCV}$-core transzgén egerekben ROS indukálta fokozott zsírsavfelvételt, illetve a sterol regulatory element binding protein (SREBP) által mediált fokozott koleszterin- és lipidszintézist írtak le [17]. Inzulinrezisztenciához (IR) vezethet a peroxiszómaproliferátor-aktivált receptor gamma (PPAR- $\gamma)$ fokozott expressziója, amit HCV-fertőzött májszövetben igazoltak. Ez a protein a glükoneogenezis iniciálásában érintett gének koaktivátora, és érintett az oxidatív stresszre kifejlődő IR-ben: aktivitása glükóz-6-foszfatáz upregulációjához és fokozott glükózképzéshez vezet [16, 21]. 


\section{A HCV és az antioxidáns-terápia: "a szilimarin story”}

Az antioxidáns, antiinflammációs, antiproliferatív és immunmoduláns hatású, 7 flavonolignant tartalmazó szilimarin a legismertebb hepatoprotektív szer. Évtizedek óta szerepel az alkoholos májbetegség terápiás eszköztárában $[1,15]$, de HCV-infekcióban is alkalmazták, ellentmondó - de leginkább negatív - eredményekkel [22]. Hazai placebokontrollos tanulmányunkban a $\mathrm{P} / \mathrm{R}$ antivirális terápia szilimarinnal történő kiegészítésének hatását, az oxidatív stressz és a virológiai válasz (SVR) alakulását vizsgálva nem tudtuk igazolni a flavonoidkomplex-szupportáció előnyét [18]. Előzőleg Polyák és mtsai in vitro rendszerekben (Huh7 sejteken és replikon szisztémában) a silibinin $\mathrm{HCV}$-t gátló hatását mutatták ki [23], majd Ferenci és mtsai IFN-re nem reagáló HCVbetegek sikeres iv. silibininkezeléséről is beszámoltak [24]. Polyák és mtsai 2013-ban elemezték a szilimarin hepatoprotektív és antivirális hatásaira vonatkozó vizsgálatokat, és arra következtettek, hogy a flavonoid célpontjai HCV-infekcióban celluláris proteinek vagy lipidmembránok lehetnek, ezeken keresztül érvényesülhet az antivirális effektus [25].

A HCV-eredetú immunmediált gyulladás és oxidatív stressz megszüntetésének a feltétele a kórokozó vírus eliminálása. Ez a több mint 90\%-ban tartós remisszióhoz (virológiai gyógyuláshoz) vezető DAA-kezelés révén mára lehetővé vált [3].

\section{Következtetések}

Az utolsó évtizedben megjelent immunológiai és szabad gyökös tanulmányok számos értékes adattal gazdagították ismereteinket a HCV okozta kórképek keletkezési mechanizmusairól, a természetes és a szerzett immunválasz, a genetikai polimorfizmusok, valamint a szabad gyökös reakciók szerepéről. A HCV-t eliminálni képes DAA-terápia egyben a HCV-infekcióval kapcsolatos számos patológiás immunológiai következmény és a szövetkárosító oxidatív stressz megelőzését, kivédését is jelenti.

Anyagi támogatás: A közlemény megírása anyagi támogatásban nem részesült.

Szerzői munkamegosztás: Mindkét szerző egyenlő mértékben vett részt a dolgozat elkészítésében. A cikk végleges változatát mindkét szerző elolvasta és jóváhagyta.

Érdekeltségek: A szerzők előadói/tanácsadói díjban és/ vagy kutatási támogatásban részesültek az alábbi gyógyszer előállítóktól/forgalmazóktól: AbbVie Kft., BMS Kft., Janssen Cilag Kft., Roche Magyarország Kft.

\section{Irodalom}

[1] Fehér, J., Vereczkei, A., Lengyel, G.: Role of free-radical reactions in liver diseases. Acta Physiol. Hung., 1992, 80(1-4), 351-361.

[2] Pár, G., Berki, T., Pálinkás, L., et al.: Immunology of HCV infection: the causes of impaired cellular immune response and the effect of antiviral treatment. [A hepatitis $\mathrm{C}$ vírus infekció immunológiája: az elégtelen cellularis immunválasz okai és az antivirális kezelés hatásai.] Orv. Hetil., 2006, 147(13), 591-600. [Hungarian]

[3] Pawlotsky, J. M.: New hepatitis C therapies: the toolbox, strategies, and challanges. Gastroenterology, 2014, 146(5), 11761192.

[4] Quaranta, M. G., Mattioli, B., Vella, S.: Glances in immunology of HIV and HCV infection. Adv. Virol., 2012, 2012, ID 134036.

[5] Park, S. H., Rehermann, B.: Immune responses to HCV and other hepatitis viruses. Immunity, 2014, 40(1), 13-24.

[6] Thimme, R.: Immunity and inflammation in chronic hepatitis $\mathrm{C}$ - Does treatment help? The American Association of the Study of the Liver Disease. 2014. Postgraduate Course. November 7-8 Boston, 2014.

[7] Mina, M. M., Luciani, F., Cameron, B., et al.: Resistance to hepatitis $C$ virus: potential genetic and immunological determinants. Lancet Infect. Dis., 2015, 15(4), 451-460.

[8] Rehermann, B., Bertoletti, A.: Immunological aspects of antiviral therapy of chronic hepatitis $B$ virus and hepatitis $C$ virus infections. Hepatology, 2015, 61(2), 712-721.

[9] Prokunina-Olsson, L., Muchmore, B., Tang, W., et al.: A variant upstream of IFNL3 (IL28B) creating a new interferon gene IFNL4 is associated with impaired clearance of hepatitis $\mathrm{C}$ virus. Nat. Genet., 2013, 45(2), 164-171.

[10] Pár, G., Szereday, L., Berki, T., et al.: Increased baseline proinflammatory cytokine production in chronic hepatitis C patients with rapid virological response to peginterferon plus ribavirin. PLoS ONE, 2013, 8(7), e67770.

[11] Pár, G., Szereday, L., Berki, T., et al.: Altered surface expression of inhibitory KIR2DL3 and activating CD160, NKG2D receptors on NK and cytotoxic T cells in chronic HCV hepatitis. J. Hepatology, 2008, 48(Suppl. 2), S51.

[12] Ge, D., Fellay, J., Thompson, A. J., et al.: Genetic variation in IL28B predicts hepatitis C treatment-induced viral clearance. Nature, 2009, 461(7262), 399-401.

[13] Pár, A., Pár, G., Tornai, I., et al.: IL28B CC genotype: a protective factor and predictor of the response to interferon treatment in chronic hepatitis C virus infection. [IL28B CC genotípus: védő tényezô és az interferonválasz prediktora krónikus hepatitis C-vírus-infekcióban.] Orv. Hetil., 2013, 154(32), 1261-1268. [Hungarian]

[14] Honda, M., Shirasaki, T., Shimakami, T., et al.: Hepatic interferon-stimulated genes are differentially regulated in the liver of chronic hepatitis $\mathrm{C}$ patients with different interleukin-28B genotypes. Hepatology, 2014, 59(3), 828-838.

[15] Fehér, J., Deák, G., Müzes, G., et al.: Liver-protective action of silymarin therapy in chronic alcoholic liver disease. [Szilimarin terápia májvédő hatása krónikus alkoholos májbetegségben.] Orv. Hetil., 1989, 130(51), 2723-2727. [Hungarian]

[16] Ivanov, A. V., Bartosch, B., Smirnova, O. A., et al.: HCV and oxidative stress in the liver. Viruses, 2013, 5(2), 439-469.

[17] Ivanov, A. V., Smirnova, O. A., Petrushanko, I. ., et al.: HCV core protein uses multiple mechanisms to induce oxidative stress in human hepatoma Huh7 cells. Viruses, 2015, 7(6), 27452770 .

[18] Pár, A., Rôth, E., Miseta, A., et al.: Effects of silymarin supplementation in patients with chronic hepatitis $C$ receiving PEG- 
IFN + ribavirin antiviral therapy. A placebo controlled double blind study. Clin. Exp. Med. J., 2009, 3(1), 119-129.

[19] Ming-Ju, H., Yih-Shou, H., Tzy-Yen, C., et al.: Hepatitis C virus E2 protein induce reactive oxygen species (ROS)-related fibrogenesis in the HSC-T6 hepatic stellate cell line. J. Cell. Biochem., 2011, 112(1), 233-243.

[20] Tsukiyama-Kohara, K.: Role of oxidative stress in hepatocarcinogenesis induced by hepatitis C virus. Int. J. Mol. Sci., 2012, 13(11), 15271-15278.

[21] Kumashiro, N., Tamura, ., Uchida, T., et al: Impact of oxidative stress and preoxisome proliferator-activated receptor gamma coactivator- 1 alpha in hepatic insulin resistance. Diabetes, 2008, 57(8), 2083-2091.

[22] Mayer, K. É., Myers, R. P., Le, S. S.: Silymarin treatment of viral hepatitis: a systematic review. J. Viral Hepat., 2005, 12(6), 559567.
[23] Polyak, S. J., Morishima, C., Shuart, M. C., et al. Inhibition of T cell-inflammatory cytokines, hepatocyte NF- $\kappa \mathrm{B}$ signaling, and $\mathrm{HCV}$ infection by standardized silymarin. Gastroenterology, 2007, 132(5), 1925-1936.

[24] Ferenci, P., Scherzer, T. M., Kerschner, H., et al.: Silibinin is a potent antiviral agent in patients with chronic hepatitis $\mathrm{C}$ not responding to pegylated interferon/ribavirin therapy. Gastroenterology, 2008, 135(5), 1561-1567.

[25] Polyak, S. J., Ferenci, P., Pawlotsky, J. M.: Hepatoprotective and antiviral functions of silimarin components in hepatitis $\mathrm{C}$ virus infection. Hepatology, 2013, 57(3), 1262-1271.

(Pár Alajos dr., Pécs, Ifjúság útja 13., 7624 e-mail: par.alajos@pte.hu)

\section{Tisztelt Szerzőink, Olvasóink!}

Az Orvosi Hetilapban megjelenő/megjelent közlemények elérhetöségére több lehetőség kínálkozik.

Rendelhető különlenyomat, melynek áráról bővebben a www.akkrt.hu honlapon (Folyóirat Szerzőknek, Különlenyomat menüpont alatt) vagy Szerkesztöségünkben tájékozódhatnak.

A közlemények megvásárolhatók pdf-formátumban is, illetve igényelhetö Optional Open Article (www.oopenart.com).

Adott dij ellenében az online közlemények bárki számára hozzáférhetök honlapunkon (a közlemények külön linket kapnak, így más oldalról is linkelhetővé válnak).

Bővebb információ a hirdetes@akkrt.hu címen vagy különlenyomat rendelése esetén a Szerkesztőségtől kérhető. 